\title{
Considering the consequences
}

t has been over a year since Lawrence Summers made his controversial comments about innate differences as a potential explanation for the under-representation of women in top science faculty positions. In the interim, Summers has resigned from his position as president of Harvard University and discussions around the US have generated many proposed strategies for dealing with the scarcity of women among senior science faculty.

Private and public universities have created committees and task forces that are actively making recommendations to ensure that that scientific academia is an environment friendly to the advancement of women. In addition, the National Academies Committee on Women in Science and Engineering is conducting studies and publishing its recommendations. Some possible recommendations are practical and are likely to positively affect the day-to-day life of many scientists. However, other recommendations, although generated with good intentions, could have negative consequences.

One recommendation, made even before Summers' comments, is to provide extra laboratory financial support for scientists with children. Harvard University's proposed Research Enabling Grants were designed on that model to alleviate the work demands on scientist parents. Such grants can be used to pay for technicians, additional managers or more-efficient equipment to assist those scientists. Similarly, the Primary Caregiver Technical Assistance Supplement pilot program of the National Institute of Allergy and Infectious Diseases provides 1-2 years of financial support for laboratories to hire technicians to assist postdoctoral parents.

Those and other similar subsidies may in fact reduce the daily demands on and increase the productivity of scientist parents. Unfortunately, scientists without children might view the situation from a different perspective- one in which those receiving the benefits are seen as being 'rewarded' for having children. If 'increased productivity' is considered the main reason for providing subsidies to scientist parents, the fact that with a technician, scientists without children could also work more efficiently must also be considered.

Another recommendation rapidly gaining ground is implementation of 'pro-diversity' changes in faculty recruitment processes. Such measures include expanding and modifying faculty searches to increase the chances that outstanding women will be included in the candidate pool, for example, by adjusting evaluation criteria to ensure that women are included on final shortlists, if necessary. Other strategies involve ensuring that one woman is included on all faculty search committees, for example, by expanding the search committee membership to include faculty from other departments or part-time faculty, if necessary. Others suggest using language in job-search announcements to make the position more appealing to women candidates. These proposals also encourage contacting departments at other universities to ask for names of promising women candidates. To implement such recommendations, many universities have created new administrative positions, and to complement these recommendations, some universities are requiring the participation of existing administration and faculty in new pro-diversity programs. Universities have acknowledged that the implementation of these measures will require substantial financial investment.

These strategies are aimed at, and might help to achieve, the necessary goal of increasing the number of women among the top echelon of science faculty. However, situations can be envisaged in which these tactics might also result in feelings of resentment (Was she hired because she is the most qualified candidate, or because she is a woman?) in those who do not directly benefit from them. Ironically, these tactics might also cause feelings of guilt (Was I hired because I am the best qualified candidate or because I am a woman?) or self-doubt (Must I now constantly prove myself among my male peers?) in those who do benefit. Such tensions on both sides could stifle collaboration. In addition, requiring the presence of women faculty on all committees and mandating participation in pro-diversity programs are likely to slow down the hiring process for everyone.

A better way to spend the large sums of money being set aside for the implementation of these recommendations would be to support some of the other, entirely positive, proposals. Providing paid maternity leave of longer duration for graduate students and postdoctoral fellows would alleviate the financial stress on young scientists thinking of starting a family. Assistance in locating or paying for extended-hours daycare would allow scientist parents to plan their experiments each day with greater ease, knowing that they have extra time to deal with equipment malfunctions or to locate a misplaced vial of antibody, just as their peers without children do. Covering the extra cost of child care incurred during travel to academic meetings might eliminate at least one troublesome consequence of leaving family for an extended period. With the support of these programs, the financial and scheduling demands on scientist parents would be alleviated without the potential of introducing unfair benefits that scientist colleagues without children could not enjoy.

Mentorship programs represent another positive move. By attending discussions with senior women faculty, junior women faculty, postdoctoral fellows and students can hear about the experiences of and choices made by women who have successfully dealt with the science-family struggle. After hearing the stories of those that went before them, young women scientists struggling to decide between science and a family might decide that the two can be balanced, and those thinking of departing the tenure path might stay the course. Summers' comments and ultimate resignation launched the longstanding 'women-in-science' issue into the national headlines. An open and honest discussion of potential positive and negative consequences of policies designed to deal with this issue would certainly benefit all in science. 